PONTIFÍCIa UNIVERSIDADE CATÓliCA do RIO dE JANEIRO

\title{
Análise Comparativa Financeira entre Flamengo e Borussia Dortmund
}

\author{
Kelvin Krein
}

Trabalho de Conclusão de Curso

Centro de ciências sociais - CCS

DePARTAMENTO de AdMINISTRAÇÃO

Graduação em Administração de Empresas 


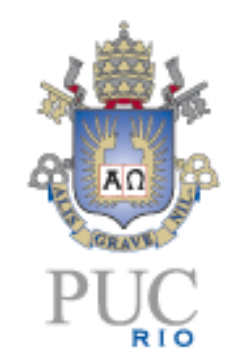

Kelvin Krein

Análise Comparativa Financeira entre Flamengo e Borussia Dortmund

Trabalho de Conclusão de Curso

Trabalho de Conclusão de Curso, apresentado ao programa de graduação em Administração da PUC-Rio como requisito parcial para a obtenção do título de graduação em Administração.

Orientador: André Cabús Klötzle

Rio de Janeiro, novembro de 2021 


\section{Agradecimentos}

Antes de mais nada, aos meus pais, Loivo e Janete Krein, pelas oportunidades e incentivo dados para que eu fosse capaz de chegar até aqui.

Ao meu irmão, William, pelos conselhos e ensinamentos ao longo da vida acadêmica e no geral.

Aos meus amigos, principalmente Carlos, Daniel, Gabriel, Pedro e Pedro Henrique pelo companheirismo e ajuda ao longo dessa trajetória.

Aos meus parceiros de Maracanã, Antoine e Patrick, que compartilham as alegrias e frustrações de ser Flamengo.

Aos meus professores, que despertaram em mim a vontade de me aprimorar como aluno, profissional e pessoa.

Aos funcionários do IAG e da PUC, pela parceria do dia a dia e serviços prestados.

A todos que participaram desse processo e que, de certa forma, fizeram com que tudo isso fosse possível.

Muito obrigado! 


\section{Resumo}

Krein, Kelvin. Análise Comparativa Financeira entre Flamengo e Borussia Dortmund. Rio de Janeiro, 2021. 28p. Trabalho de Conclusão de Curso Departamento de Administração. Pontifícia Universidade Católica do Rio de Janeiro.

O objetivo principal deste trabalho consiste em calcular e analisar os principais indicadores financeiros de Flamengo e Borussia Dortmund, dois times com diversos aspectos comparáveis, a fim de destrinchar e comparar, em números, quem possui a melhor gestão financeira. Durante o estudo foram verificadas virtudes e fraquezas de ambos os times, junto de suas justificativas. Ao final da análise foi concluído que o clube alemão possui números e resultados financeiros mais expressivos do que os do clube carioca, porém ambos se encontram em posições consolidadas financeiramente dentro de cada realidade local.

\section{Palavras-chave:}

Flamengo, Borussia Dortmund, Gestão Financeira, Análise Financeira, Indicadores Financeiros.

\section{Abstract}

Krein, Kelvin. Comparative Financial Analysis between Flamengo and Borussia Dortmund. Rio de Janeiro, 2021. 28p. Trabalho de Conclusão de Curso - Departamento de Administração. Pontifícia Universidade Católica do Rio de Janeiro.

The main objective of this work consists of calculating and analyzing the main financial indicators of Flamengo and Borussia Dortmund, two teams with several comparable aspects, in order to break down and compare, in numbers, who gets the best financial management. During the study, strengths and weaknesses of both teams were verified, along with their justifications. At the end of the analysis, it was concluded that the German club has more expressive numbers and financial results than those of the Rio de Janeiro club, but both are in financially consolidated positions within each local reality.

\section{Key words:}

Flamengo, Borussia Dortmund, Financial Management, Financial Analysis, Financial Indicators. 


\section{Sumário}

1. Introdução 1

1.1. Contexto 1

1.2. Objetivo Principal 2

1.3. Delimitação 3

1.4. Relevância 3

2. Referencial Teórico 4

2.1. Governança Corporativa 4

2.2. Indicadores Financeiros 5

2.2.1. Indicadores de Liquidez 6

2.2.2. Estrutura de Capital 7

$\begin{array}{ll}\text { 2.2.3. Indicadores de Rentabilidade e Lucratividade } & 7\end{array}$

3. Metodologia 9

3.1. Etapa de Coleta de Dados 9

3.2. Procedimentos e Instrumentos de Coleta de Dados 9

3.3. Limitações do Estudo 9

4. Apresentação e Análise dos Resultados 11

4.1. Análise Horizontal dos Balanços Patrimoniais 11

4.2. Análise Vertical dos Balanços Patrimoniais 15

4.3. Comparativo entre Clubes 18

4.3.1. Liquidez Geral 18

4.3.2. Liquidez Corrente 19

4.3.3. Liquidez Imediata 19

4.3.4. Participação do Capital de Terceiros 20

4.3.5. Composição do Endividamento 20

4.3.6. Imobilização do Patrimônio Líquido 21

4.3.7. Margem Líquida 22

4.3.8. ROA 22

$\begin{array}{ll}\text { 4.3.9. ROE } & 23\end{array}$ 


\section{Lista de Tabelas}

Tabela 1: Análise Horizontal dos Ativos do Flamengo .................................... 11

Tabela 2 Análise Horizontal dos Passivos + Patrimônio Líquido do Flamengo .. 11

Tabela 3: Análise Horizontal dos Ativos do Borussia Dortmund ....................... 12

Tabela 4: Análise Horizontal dos Passivos + Patrimônio do Borussia Dortmund 12

Tabela 5: Análise Vertical dos Ativos do Flamengo ........................................ 15

Tabela 6: Análise Vertical do Passivos + Patrimônio Líquido do Flamengo ....... 15

Tabela 7: Análise Vertical dos Ativos do Borussia Dortmund .......................... 16

Tabela 8: Análise Vertical dos Passivos + Patrimônio Líquido do Borussia

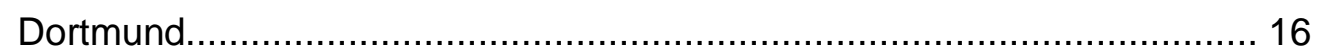

Tabela 9: Comparação Liquidez Geral .......................................................... 18

Tabela 10: Comparação Liquidez Corrente ................................................... 19

Tabela 11: Comparação Liquidez Imediata ................................................ 19

Tabela 12: Comparação Participação do Capital de Terceiros ........................... 20

Tabela 13: Comparação Composição do Endividamento ................................ 20

Tabela 14: Comparação da Imobilização do Patrimônio Líquido ....................... 21

Tabela 15: Comparação Margem Líquida ................................................... 22

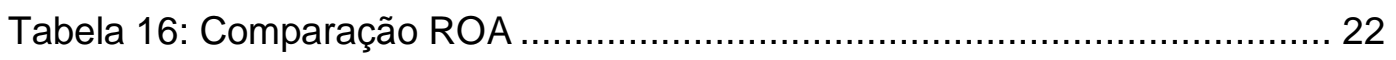

Tabela 17: Comparação ROE ................................................................. 23 


\section{Introdução}

\subsection{Contexto}

O futebol, esporte criado na Inglaterra no século XIX, segundo a Federação Internacional de Futebol (FIFA), trata-se do esporte mais popular do mundo, segundo pesquisa publicada no World Football Report, feita pela Nielsen Sports (2018). No entanto, o maior ganhador da competição mais importante a nível profissional no mundo - a Copa do Mundo - é o Brasil, com cinco conquistas, de acordo com a Confederação Brasileira de Futebol (CBF). Conhecido não só por elas, o país também sempre foi apontado como praticante de um futebol ofensivo, irreverente e vistoso pelos seus espectadores, como citam Zico - um dos jogadores de futebol reconhecido como um dos maiores de todos os tempos pela Federação Internacional da História do Futebol e Estatística (IFFHS) - e Juca Kfouri - jornalista esportivo renomado.

Contudo, tais características passaram a ser questionadas após a derrota acachapante da Seleção Brasileira para a Alemanha na semifinal da Copa do Mundo de 2014, realizada no Brasil, por um placar de 7 a 1 . Torcedores e imprensa, antes confiantes e otimistas, passaram a contestar a tal superioridade técnica por parte dos jogadores brasileiros, até então inquestionável. Além disso, a derrota fez com que surgissem à tona questões em torno da organização do futebol brasileiro, sua estrutura e seus investimentos, uma vez que triunfos em competições no passado fizeram com que isso passasse despercebido, de acordo com João Paulo Medina - fundador da Universidade do Futebol - em entrevista à BBC.

As discrepâncias de organização e estrutura foram apontadas à época como as principais razões pelo placar latente daquele jogo, como afirmou João Paulo Medina. Tais motivos fizeram com que outras seleções, como a própria Alemanha, Itália e França diminuíssem a diferença técnica em relação ao Brasil, considerado referência no passado. Outro fator exposto pela opinião pública foi a falta de coletividade evidenciada pelo time brasileiro na ocasião, que tornava o mesmo previsível e dependente de lampejos individuais de seus craques, enquanto os rivais apresentavam justamente o contrário dentro de campo. 
Logo, é possível estabelecer um paralelo entre o momento vivido pela Seleção Brasileira após a derrota por 7 a 1 e o momento vivido pelo Flamengo antes da mudança de gestão, em 2013, no que diz respeito ao mau gerenciamento de recursos.

Até a eleição de 2013 no Flamengo eleger Eduardo Bandeira de Mello, executivo ligado ao Banco Nacional de Desenvolvimento (BNDES), o clube era conhecido por sua má gestão financeira, desorganização e falta de estrutura, conforme afirmou Claudio Pracownik - ex-vice-presidente de Finanças do Flamengo - em entrevista ao jornal argentino El País (2018) e Zinho - exgerente de futebol do clube carioca - ao site do Globo Esporte (GE) (2013). O clube era alvo de penhoras em suas contas, oriundas principalmente de ações trabalhistas e fiscais e não conseguia realizar investimentos e honrar salários de jogadores e funcionários em dia, como afirmou o ex-vice-presidente à revista Lance (2019). Muitos desses acabavam acionando o clube para garantir seus direitos e alguns, em detrimento disso, conseguiam sua desvinculação da associação esportiva por meio unilateral, como aconteceu com o Ronaldinho em 2012, de acordo com o GE (2012). Além disso, o Rubro-Negro também vivia asfixiado financeiramente por conta da falta de Certidões Negativas de Débito, uma vez que detinha dívidas com o Estado, que dificultavam a captação de recursos e patrocínios de instituições públicas, conforme o próprio Flamengo em seu site oficial. Outro aspecto que deve ser mencionado era a falta de credibilidade do Flamengo junto ao mercado de crédito privado, o que dificultava consideravelmente a obtenção de recursos para o clube ou a impossibilitava.

Sendo assim, faz-se o questionamento: a gestão financeira eficiente tem relevância no que tange à obtenção de resultados esportivos?

\subsection{Objetivo Principal}

O objetivo principal deste trabalho é comparar as gestões financeiras de Flamengo e Borussia Dortmund, por meio de demonstrações contábeis e suas evoluções durante o período avaliado, levando em consideração a realidade de cada clube. 


\subsection{Delimitação}

Para análise deste estudo serão utilizadas informações financeiras do período entre 2013 e 2019, uma vez que os dados do Flamengo passaram a ser divulgados de forma confiável a partir de 2013. A escolha pelo Borussia Dortmund passa também pela confiabilidade dos dados, visto que o clube tem ações listadas na DAX - Bolsa de Valores da Alemanha - além de ter similaridades no que tange à tradição, tamanho de torcida, histórico financeiro conturbado e recentes mudanças de governança. As informações serão extraídas e analisadas apenas com base nos balanços patrimoniais divulgados pelos clubes oficialmente. É importante mencionar que os dados de 2020 não foram incluídos no estudo pelo fato de eles sofrerem distorções que afetariam a análise, devido à pandemia e seus impactos na operação dos clubes.

\subsection{Relevância}

A eficiência da utilização de recursos é primordial para qualquer indivíduo ou instituição cujo objetivo seja ter êxito no que diz respeito à gestão financeira. Tal fator passa a ser ainda mais importante em setores onde existe grande competitividade e/ou recursos limitados. Neste caso, o trabalho visa realizar uma análise comparativa financeira com o intuito de dar um parecer em relação à qualidade da gestão de cada clube. O impacto da alocação de recursos inadequada pode afetar drasticamente seu desempenho esportivo, além de comprometer a saúde financeira dos clubes, podendo limitar sua capacidade de investir em estrutura e recursos técnicos (jogadores e comissão técnica) melhores. Sendo assim, é interessante realizar a comparação entre um clube europeu, mais especificamente alemão, e um clube brasileiro a fim de analisar o peso da gestão financeira para se obter sucesso dentro de campo, além de entender melhor como é possível torná-la mais eficiente. 


\section{Referencial Teórico}

\subsection{Governança Corporativa}

De acordo com Maria da Conceição Marques (2007), o conceito de governança corporativa pode ser definido como o conjunto de mecanismos ou princípios que regem o processo decisório dentro de uma organização, além de regras que buscam diminuir eventuais riscos e problemas de agência. Ela abrange sócios, conselho de administração, colaboradores, diretoria, órgãos de fiscalização, entre outros.

De acordo com o Instituto Brasileiro de Governança Corporativa (IBGC), se adotados os princípios básicos de governança corporativa, é estabelecido maior grau de confiabilidade tanto internamente quanto nas relações com terceiros. Além disso, boas práticas de governança corporativa permitem que os investidores tenham maior controle sobre a empresa e reduzam a discricionariedade dos gestores, segundo Fontes Filho e Picolin (2005). Os gestores perdem um pouco de sua autonomia, no entanto, compartilham as decisões e obtêm apoio e orientação do conselho de administração, que facilita a comunicação com os acionistas. Tais princípios são: transparência, equidade, prestação de contas e responsabilidade corporativa.

No que diz respeito à transparência, o IBGC a aponta como o desejo de disponibilizar informações às partes interessadas, independentemente do desempenho econômico-financeiro da instituição e cujo objetivo é a preservação e otimização do valor da organização. A equidade se dá em torno do tratamento justo e isonômico de todas as partes interessadas, inclusive sócios e gestores, levando em consideração direitos, deveres, necessidades, interesses e expectativas. Em relação à prestação de contas, o IBGC indica que os agentes de governança devem prestar contas de sua atuação de modo claro, conciso, compreensível e tempestivo, assumindo integralmente as consequências de seus atos e omissões e atuando com diligência e responsabilidade no âmbito de seus papeis. No que tange à responsabilidade corporativa, os agentes de governança devem zelar pela viabilidade econômico-financeira das instituições, reduzir as externalidades negativas de seus negócios e suas operações e 
aumentar as positivas, em diferentes horizontes de tempo (curto, médio e longo prazos).

\subsection{Indicadores Financeiros}

Indicadores financeiros são referências utilizadas como forma de controle e análise de determinados fatores e/ou processos das instituições e auxiliam os gestores na tomada de decisão.

A partir do balanço patrimonial, que pode ser definido como uma fotografia em determinado período, geralmente de um ano, de acordo com Assaf (2015), é possível extrair uma série de informações extremamente relevantes para entendimento da situação financeira da empresa ou instituição. A estrutura dele é consistida por duas colunas, cuja coluna da esquerda consiste em ativos (bens e direitos) e a direita em passivos, que se tratam das fontes de recursos e origens de financiamentos, logo, suas obrigações para com terceiros.

Dentro de cada coluna, existem grupos de contas que são distribuídas para melhor entendimento e leitura do balanço, segundo Assaf (2015). Na coluna de ativos, os grupos são ativo circulante e não circulante e dentro do ativo não circulante há outra subdivisão, sendo ela realizável a longo prazo. As contas do ativo circulante são as que vencerão dentro daquele exercício - ano, geralmente, conforme apontado anteriormente - e dentro desse grupo há quatro subdivisões, de acordo com o autor: disponível, valores a receber no curto prazo, estoques e despesas antecipadas. A coluna de passivos (à direita) é consistida por passivo circulante, passivo exigível e patrimônio líquido. Em relação ao exigível, se trata de dívidas e/ou obrigações da instituição, cujas origens podem ser de empréstimos, emissão de títulos de dívida, desconto de duplicatas, entre outros meios de financiamento. O passivo exigível é divido em duas outras contas: passivo circulante e não circulante, sendo o circulante relacionado às obrigações de curto prazo. Em relação ao patrimônio líquido, é possível afirmar que se trata da diferença entre ativos e passivos, conforme cita o autor.

O outro demonstrativo contábil relevante para entendimento da situação financeira da instituição é o Demonstrativo de Resultado do Exercício (DRE), que ilustra o desempenho da empresa durante um período - de um ano, geralmente - de acordo com Assaf (2015).

Com esses relatórios contábeis, é possível extrair informações e utilizar indicadores financeira, que nada mais são do que ferramentas de comparação e análise, que auxiliam na tomada de decisão. A utilização desses indicadores é 
essencial para o objetivo de comparação entre dois clubes deste trabalho. Entre os diversos indicadores disponíveis, a escolha se deu pelos que estão mencionados abaixo.

\subsubsection{Indicadores de Liquidez}

Segundo o autor, esses indicadores têm como principal objetivo demonstrar a solidez da empresa, contrapondo receitas com dívidas. Por meio deles, é possível compreender melhor a real situação financeira da instituição.

\subsubsection{Liquidez Geral}

O indicador demonstra a capacidade do clube ou empresa de arcar com suas dívidas. Segundo o autor, ele é composto por ativo circulante e realizável a longo prazo sobre passivo circulante e passivo não circulante. Caso a razão desses fatores seja maior que um, significa que a organização se encontra em plenas condições de honrar seus compromissos, enquanto se for menor, deverá se preocupar em gerar recursos para que seja capaz de arcar com suas obrigações.

\subsubsection{Liquidez Corrente}

O índice é composto pelo ativo circulante sobre passivo circulante e indica a capacidade da instituição se financiar no curto prazo. Assim como na liquidez geral, quanto maior for a razão entre esses dois componentes, pode-se considerar o clube/empresa mais saudável financeiramente.

\subsubsection{Liquidez Imediata}

Tal fator aponta a razão entre ativos disponíveis e passivo circulante, ou seja, quanto caixa a instituição possui para honrar seus compromissos de curto prazo. Ele não leva em consideração qualquer conta a receber ou estoque. Quanto maior for a razão, melhor se encontra a situação financeira no curto prazo. 


\subsubsection{Estrutura de Capital}

Os indicadores desse conjunto concentram as origens e aplicação dos recursos da instituição.

\subsubsection{Participação do Capital de Terceiros}

O índice demonstra quanto o clube/empresa tomou emprestado para se financiar. Ele é composto pela soma do passivo circulante com passivo não circulante sobre o patrimônio líquido. Ao contrário dos indicadores de liquidez, quanto menor a razão, geralmente é melhor, uma vez que indica menor dependência de fontes externas.

\subsubsection{Composição do Endividamento}

A composição do endividamento se trata do passivo circulante sobre a soma do passivo circulante e passivo não circulante. Tal fator aponta a proporção das obrigações de curto prazo em relação a todas as obrigações. Também como no item anterior, quanto menor a razão, melhor, já que permite melhor visualização da urgência de pagamento das dívidas. Com isso, auxilia no planejamento e tomada de decisão.

\subsubsection{Imobilização do Patrimônio Líquido}

O item é uma razão entre ativo permanente sobre patrimônio líquido. De acordo com Assaf (2015), quanto mais recurso for aplicado no ativo permanente, menos capital próprio haverá para o ativo circulante, tornando a instituição mais dependente do capital de terceiros para financiar o ativo circulante.

\subsubsection{Indicadores de Rentabilidade e Lucratividade}

Os indicadores desse grupo apontam o retorno do capital investido, ajudando a quantificar o sucesso financeiro da empresa/clube.

\subsubsection{Margem Líquida}

A margem líquida aponta qual foi o lucro do clube/empresa em relação à sua receita, ou seja, lucro líquido sobre total da receita. Por meio desse indicador, é 
possível entender se a empresa está sendo rentável e verificar a eficiência do uso dos recursos, visto que quanto maior for a razão dos componentes citados anteriormente, mais eficiente a instituição é. A comparação desse índice entre empresas do mesmo setor costuma ser uma boa referência para auxiliar nesse processo.

\subsubsection{ROA}

A conta é composta pelo lucro líquido sobre o total do ativo. Esse indicador demonstra quanto o investimento gerou de lucro para a empresa/clube. Assim, é possível verificar a capacidade dos ativos em gerar resultados para a organização. No entanto, pode não representar muito bem a realidade quando aplicado aos clubes de futebol, uma vez que grande parte dos ativos deles tem alta volatilidade, visto que se tratam de jogadores de futebol, cuja performance tem relação direta com seu valor e podem variar drasticamente em um curto espaço de tempo.

\subsubsection{ROE}

Tal indicador indica quanto o clube/empresa obteve de lucro em relação ao seu capital próprio, ou seja, trata-se do lucro líquido sobre patrimônio líquido. Quanto maior for o resultado dessa conta, melhor. 


\section{Metodologia}

\subsection{Etapa de Coleta de Dados}

Para recolher os dados, foram utilizados demonstrativos financeiros dos clubes entre os anos de 2013 e 2019, disponíveis nos sites dos próprios. A garantia de confiabilidade dos números passa pelo fato de que tanto Flamengo quanto Borussia Dortmund têm os mesmos auditados por auditorias independentes, que dão seus pareceres de forma autônoma.

A partir dessas informações, foi realizado o cálculo dos índices mencionados anteriormente e com eles, foi possível fazer a análise comparativa entre as instituições.

\subsection{Procedimentos e Instrumentos de Coleta de Dados}

Além dos dados fornecidos pelos próprios clubes, foram utilizadas outras publicações e livros de autores financeiros para as bases teóricas, assim como estudos e matérias de portais e jornais relevantes ao tema.

A ferramenta utilizada para processar os dados coletados foi o Excel, uma vez que se trata de um instrumento capaz de calcular os indicadores financeiros de forma precisa, assim como é de amplo conhecimento dos alunos de Administração, visto que está inserida em diversas matérias ao longo do curso. Além disso, o Excel permite melhor visualização das informações por meio de suas funções.

\subsection{Limitações do Estudo}

A ideia inicial do estudo era realizar a comparação de indicadores financeiros entre algum clube europeu e o Flamengo. No entanto, uma parcela relevante de clubes europeus pertence a magnatas, cuja origem de suas fortunas surgiu a partir de outras fontes, podendo distorcer o resultado da análise. Uma vez que boa parte das instituições é privada, muitos não divulgam seus dados publicamente. 
Portanto, a escolha pelo Borussia Dortmund passa pela regra da liga alemã (DFL), que impede que investidores externos detenham controle da maioria das ações e com isso, seus votos. Assim, os clubes são protegidos de interesses comerciais voltados ao lucro, impedindo associação de terceiros, onde a relação com o clube é mínima ou nenhuma, salvo exceções previstas.

É possível estabelecer uma relação com o Flamengo, uma vez que também não possui controle privado, visto que se trata de uma associação esportiva sem fins lucrativos. Tal modelo é amplamente utilizado no futebol brasileiro, devido principalmente aos incentivos fiscais previstos no regime jurídico e uma legislação confusa, segundo Vinícius Lordello (Cegalini, 2017), especialista em gestão e estratégia desportiva. 


\section{Apresentação e Análise dos Resultados}

\subsection{Análise Horizontal dos Balanços Patrimoniais}

Tabela 1: Análise Horizontal dos Ativos do Flamengo ( $\$$ \$ 1.000)

\begin{tabular}{|l|c|c|c|c|c|c|c|c|c|c|c|c|c|c|}
\hline \multicolumn{10}{|c|}{ Balanço Patrimonial } \\
\hline \multicolumn{1}{|c|}{ Ativo } & $\mathbf{2 0 1 9}$ & $\%$ An Hor & $\mathbf{2 0 1 8}$ & $\%$ An Hor & $\mathbf{2 0 1 7}$ & $\%$ An Hor & $\mathbf{2 0 1 6}$ & $\%$ & An Hor & $\mathbf{2 0 1 5}$ & $\%$ An Hor & $\mathbf{2 0 1 4}$ & $\%$ An Hor & $\mathbf{2 0 1 3}$ \\
\hline Ativo Circulante & 202.467 & $134 \%$ & 86.668 & $39 \%$ & 62.312 & $37 \%$ & 45.615 & $-60 \%$ & 113.686 & $9 \%$ & 104.207 & $61 \%$ & 64.740 \\
\hline Caixa Disponível & 87.649 & $993 \%$ & 8.016 & $-33 \%$ & 11.935 & $-5 \%$ & 12.526 & $-54 \%$ & 27.257 & $51 \%$ & 18.030 & $50 \%$ & 12.034 \\
\hline Contas a Receber & 86.120 & $96 \%$ & 43.988 & $96 \%$ & 22.455 & $37 \%$ & 16.415 & $-61 \%$ & 42.379 & $17 \%$ & 36.149 & $60 \%$ & 22.664 \\
\hline Adiantamentos & 16.383 & $1136 \%$ & 1.325 & $-49 \%$ & 2.602 & $64 \%$ & 1.584 & $31 \%$ & 1.212 & $-2 \%$ & 1.241 & $218 \%$ & 390 \\
\hline Depósitos Judiciais & & - & 17.261 & $16 \%$ & 14.898 & $13 \%$ & 13.148 & $-69 \%$ & 42.757 & $-12 \%$ & 48.538 & $65 \%$ & 29.365 \\
\hline Outros & 12.315 & $-23 \%$ & 16.077 & $54 \%$ & 10.422 & $437 \%$ & 1.942 & $2298 \%$ & 81 & $-68 \%$ & 249 & $-13 \%$ & 286 \\
\hline Ativo Não Circulante & 676.359 & $34 \%$ & 503.582 & $-6 \%$ & 536.041 & $22 \%$ & 437.804 & $30 \%$ & 337.686 & $4 \%$ & 325.703 & $3 \%$ & 317.310 \\
\hline Contas a Receber & 3.287 & $-69 \%$ & 10.611 & $-91 \%$ & 114.573 & $92 \%$ & 59.718 & $1240 \%$ & 4.456 & $27 \%$ & 3.519 & $7 \%$ & 3.275 \\
\hline Depósitos Judiciais & 39.539 & $78 \%$ & 22.202 & $-3 \%$ & 22.846 & $80 \%$ & 12.673 & $400 \%$ & 2.537 & $-25 \%$ & 3.393 & - & \\
\hline Investimentos & 104.948 & $0 \%$ & 104.966 & $-20 \%$ & 130.485 & $-2 \%$ & 132.519 & $-3 \%$ & 136.584 & $-1 \%$ & 138.625 & $-6 \%$ & 147.042 \\
\hline Imobilizado & 202.432 & $8 \%$ & 187.800 & $8 \%$ & 174.608 & $10 \%$ & 158.753 & $8 \%$ & 147.146 & $3 \%$ & 142.591 & $6 \%$ & 134.542 \\
\hline Intangível & 326.153 & $83 \%$ & 178.003 & $90 \%$ & 93.529 & $26 \%$ & 74.141 & $58 \%$ & 46.963 & $25 \%$ & 37.575 & $16 \%$ & 32.450 \\
\hline & & & & & & & & & & & & & \\
\hline & & & & & & & & & & & & & \\
\hline \multicolumn{1}{c}{ Total do Ativo } & 878.826 & $49 \%$ & 590.250 & $-1 \%$ & 598.353 & $24 \%$ & 483.419 & $7,1 \%$ & 451.372 & $5,0 \%$ & 429.910 & $13 \%$ & 382.050 \\
\hline
\end{tabular}

Fonte: Elaboração própria

Tabela 2 Análise Horizontal dos Passivos + Patrimônio Líquido do Flamengo (R\$1.000)

\begin{tabular}{|c|c|c|c|c|c|c|c|c|c|c|c|c|c|c|}
\hline \multicolumn{10}{|c|}{ Balanço Patrimonial } \\
\hline \multicolumn{1}{|c|}{ Passivo } & $\mathbf{2 0 1 9}$ & $\%$ An Hor & $\mathbf{2 0 1 8}$ & $\%$ An Hor & $\mathbf{2 0 1 7}$ & $\%$ An Hor & $\mathbf{2 0 1 6}$ & $\%$ An Hor & $\mathbf{2 0 1 5}$ & $\%$ An Hor & $\mathbf{2 0 1 4}$ & $\%$ An Hor & $\mathbf{2 0 1 3}$ \\
\hline Passivo Circulante & 317.127 & $57 \%$ & 201.859 & $-2 \%$ & 206.331 & $-7 \%$ & 222.583 & $-16 \%$ & 263.716 & $-4 \%$ & 274.697 & $24 \%$ & 221.958 \\
\hline Contas a Pagar & 162.226 & $67 \%$ & 97.111 & $31 \%$ & 74.291 & $-44 \%$ & 131.677 & $-13 \%$ & 150.796 & $18 \%$ & 127.950 & $43 \%$ & 89.560 \\
\hline Obrigações Trabalhistas & 96.000 & $147 \%$ & 38.814 & $9 \%$ & 35.731 & $25 \%$ & 28.640 & $26 \%$ & 22.738 & $-29 \%$ & 32.197 & $-14 \%$ & 37.554 \\
\hline Provisão para Contigência & - & - & 12.438 & $-55 \%$ & 27.365 & $5 \%$ & 26.165 & $-53 \%$ & 55.099 & $-26 \%$ & 74.653 & $16 \%$ & 64.545 \\
\hline Receitas a Realizar & 58.901 & $10 \%$ & 53.496 & $-22 \%$ & 68.944 & $91 \%$ & 36.101 & $3 \%$ & 35.083 & $-12 \%$ & 39.896 & $32 \%$ & 30.119 \\
\hline Passivo Não Circulante & 433.568 & $12 \%$ & 387.163 & $18 \%$ & 328.080 & $-8 \%$ & 355.993 & $-18 \%$ & 436.295 & $-18 \%$ & 534.302 & $-11 \%$ & 603.493 \\
\hline Contas a Pagar & 64.906 & $2070 \%$ & 2.991 & $-82 \%$ & 16.491 & $-49 \%$ & 32.289 & $-60 \%$ & 81.536 & $-4 \%$ & 84.914 & $-13 \%$ & 97.781 \\
\hline Obrigações Tributárias & 217.593 & $-23 \%$ & 281.273 & $1 \%$ & 278.560 & $5 \%$ & 264.241 & $6 \%$ & 250.238 & $-24 \%$ & 329.222 & $-6 \%$ & 349.131 \\
\hline Provisão para Contigência & 86.451 & $186 \%$ & 30.223 & $82 \%$ & 16.562 & $-36 \%$ & 25.713 & $-38 \%$ & 41.618 & $6 \%$ & 39.331 & $-28 \%$ & 54.898 \\
\hline Receitas a Realizar & 64.618 & $-11 \%$ & 72.675 & $339 \%$ & 16.547 & $-51 \%$ & 33.750 & $-46 \%$ & 62.903 & $-22 \%$ & 80.835 & $-21 \%$ & 101.683 \\
\hline Patrimônio Líquido & 128.131 & $10334 \%$ & 1.228 & $-98 \%$ & 63.942 & $-167 \%$ & -95.157 & $-62 \%$ & -248.639 & $-34 \%$ & -379.089 & $-15 \%$ & -443.401 \\
\hline Patrimônio Social & 240.011 & $-1 \%$ & 243.341 & $-1 \%$ & 245.907 & $-1 \%$ & 248.896 & $-4 \%$ & 259.123 & $-1 \%$ & 262.114 & $0 \%$ & 261.447 \\
\hline Resultado Acumulado & -111.880 & $-54 \%$ & -242.113 & $33 \%$ & -181.965 & $-47 \%$ & -344.053 & $-32 \%$ & -507.762 & $-21 \%$ & -641.203 & $-9 \%$ & -704.848 \\
\hline & & & & & & & & & & & & & \\
\hline Total do Passivo & 878.826 & $49 \%$ & 590.250 & $-1 \%$ & 598.353 & $24 \%$ & 483.419 & $7,1 \%$ & 451.372 & $5,0 \%$ & 429.910 & $13 \%$ & 382.050 \\
\hline
\end{tabular}

Fonte: Elaboração própria 
Tabela 3: Análise Horizontal dos Ativos do Borussia Dortmund (€1.000)

\begin{tabular}{|l|c|c|c|c|c|c|c|c|c|c|c|c|c|c|c|}
\hline \multicolumn{10}{|c|}{ Balanço Patrimonial } \\
\hline \multicolumn{1}{|c|}{ Ativo } & $2018 / 19$ & An Hor & $2017 / 18$ & An Hor & $2016 / 17$ & $\%$ & An Hor $2015 / 16$ & An Hor 2014/15 \% An Hor 2013/14 \% An Hor 2012/13 \\
\hline \multicolumn{1}{|c|}{ Ativo Circulante } & 121.952 & $-17 \%$ & 147.027 & $3 \%$ & 143.294 & $-12 \%$ & 162.698 & $80 \%$ & 90.526 & $145 \%$ & 36.979 & $-56 \%$ & 84.993 \\
\hline Caixa Disponivel & 52.120 & $-5 \%$ & 54.911 & $21 \%$ & 45.360 & $-9 \%$ & 49.682 & $-6 \%$ & 53.019 & $215 \%$ & 16.858 & $46 \%$ & 11.539 \\
\hline Contas a Receber & 39.085 & $-38 \%$ & 62.819 & $1 \%$ & 62.228 & $-31 \%$ & 90.678 & $352 \%$ & 20.057 & $62 \%$ & 12.413 & $-81 \%$ & 66.756 \\
\hline Adiantamentos & - & - & - & - & - & - & - & - & - & - & - & - & - \\
\hline Depósitos Judiciais & - & - & - & - & - & - & - & - & - & - & - & - & - \\
\hline Outros & 30.747 & $5 \%$ & 29.297 & $-18 \%$ & 35.706 & $60 \%$ & 22.338 & $28 \%$ & 17.450 & $126 \%$ & 7.708 & $15 \%$ & 6.698 \\
\hline Ativo Não Circulante & 391.754 & $12 \%$ & 349.426 & $1 \%$ & 344.415 & $28 \%$ & 269.708 & $-10 \%$ & 300.168 & $13 \%$ & 265.861 & $30 \%$ & 204.967 \\
\hline Contas a Receber & - & - & - & - & - & - & - & - & - & - & - & - & - \\
\hline Depósitos Judiciais & - & - & - & - & - & - & - & - & - & - & - & - & - \\
\hline Investimentos & 11.743 & $-15 \%$ & 13.770 & $-12 \%$ & 15.650 & $2 \%$ & 15.366 & $3 \%$ & 14.930 & $4 \%$ & 14.345 & $-90 \%$ & 140.367 \\
\hline Imobilizado & 195.553 & $0 \%$ & 195.487 & $4 \%$ & 187.579 & $-1 \%$ & 189.154 & $0 \%$ & 188.662 & $0 \%$ & 189.565 & $431 \%$ & 35.729 \\
\hline Intangível & 184.458 & $32 \%$ & 140.169 & $-1 \%$ & 141.186 & $117 \%$ & 65.188 & $-33 \%$ & 96.576 & $56 \%$ & 61.951 & $115 \%$ & 28.871 \\
\hline & & & & & & & & & & & & & \\
\hline & & & & & & & & & & & & & \\
\hline Total do Ativo & 513.706 & $3 \%$ & 496.453 & $2 \%$ & 487.709 & $13 \%$ & 432.406 & $11 \%$ & 390.694 & $29 \%$ & 302.840 & $4 \%$ & 289.960 \\
\hline
\end{tabular}

Fonte: Elaboração própria

Tabela 4: Análise Horizontal dos Passivos + Patrimônio do Borussia

\section{Dortmund $(€ 1.000)$}

\begin{tabular}{|c|c|c|c|c|c|c|c|c|c|c|c|c|c|}
\hline \multicolumn{14}{|c|}{ Balanço Patrimonial } \\
\hline Passivo & $2018 / 19$ & $6 \mathrm{An} \mathrm{Ho}$ & $2017 / 18$ & $6 \mathrm{An} \mathrm{Ho}$ & $2016 / 17$ & $\% \mathrm{An} \mathrm{Ho}$ & $2015 / 16$ & ${ }_{0} \mathrm{An} \mathrm{HC}$ & $2014 / 15$ & $\% \mathrm{An} \mathrm{Ho}$ & $2013 / 14$ & $\% \mathrm{An} \mathrm{Ho}$ & $2012 / 13$ \\
\hline Passivo Circulante & 102.511 & $5 \%$ & 97.277 & $-19 \%$ & 119.465 & $77 \%$ & 67.358 & $9 \%$ & 61.972 & $-21 \%$ & 78.511 & $-1 \%$ & 79.317 \\
\hline Contas a Pagar & 77.353 & $12 \%$ & 68.914 & $-23 \%$ & 89.906 & $156 \%$ & 35.076 & $36 \%$ & 25.699 & $-32 \%$ & 37.691 & $-9 \%$ & 41.204 \\
\hline Obrigações Trabalhistas & 36 & $24 \%$ & 29 & $53 \%$ & 19 & $27 \%$ & 15 & $7 \%$ & 14 & $-13 \%$ & 16 & $100 \%$ & 8 \\
\hline Provisão para Contigência & - & - & - & - & - & - & - & - & - & - & - & - & - \\
\hline Receitas a Realizar & 25.122 & $-11 \%$ & 28.334 & $-4 \%$ & 29.540 & $-8 \%$ & 32.267 & $-11 \%$ & 36.259 & $-11 \%$ & 40.804 & $7 \%$ & 38.105 \\
\hline Passivo Não Circulante & 21.677 & $-28 \%$ & 29.983 & $50 \%$ & 19.937 & $14 \%$ & 17.561 & $258 \%$ & 4.899 & $-87 \%$ & 37.499 & $33 \%$ & 28.237 \\
\hline Contas a Pagar & 8.705 & $-29 \%$ & 12.274 & $73 \%$ & 7.096 & $107 \%$ & 3.420 & - & 0 & $-100 \%$ & 32.189 & $117 \%$ & 14.858 \\
\hline Obrigaçôes Tributárias & 807 & $-59 \%$ & 1.946 & $230 \%$ & 590 & $-88 \%$ & 5.072 & $614 \%$ & 710 & $78 \%$ & 398 & $-90 \%$ & 3.956 \\
\hline Provisão para Contigência & 12.165 & $-23 \%$ & 15.763 & $29 \%$ & 12.251 & $35 \%$ & 9.069 & $116 \%$ & 4.189 & $-15 \%$ & 4.912 & $-48 \%$ & 9.423 \\
\hline Receitas a Realizar & - & - & - & - & - & - & - & - & - & - & - & - & - \\
\hline Patrimônio Líquido & 389.518 & $6 \%$ & 369.193 & $6 \%$ & 348.307 & $0 \%$ & 347.487 & $7 \%$ & 323.823 & $73 \%$ & 186.830 & $2 \%$ & 182.406 \\
\hline Patrimônio Social & 363.674 & $6 \%$ & 342.788 & $0 \%$ & 341.968 & $7 \%$ & 319.225 & $0 \%$ & 319.223 & $81 \%$ & 176.272 & $36 \%$ & 129.148 \\
\hline Resultado no Período & 25.844 & $-2 \%$ & 26.405 & $317 \%$ & 6.339 & $-78 \%$ & 28.262 & $514 \%$ & 4.600 & $-56 \%$ & 10.558 & $-80 \%$ & 53.258 \\
\hline Total do Passivo & 513.706 & $3 \%$ & 496.453 & $2 \%$ & 487.709 & $13 \%$ & 432.406 & $11 \%$ & 390.694 & $29 \%$ & 302.840 & $4 \%$ & 289.960 \\
\hline
\end{tabular}

Fonte: Elaboração própria

A partir da análise da evolução das rubricas mais significativas durante o período, é possível compreender um pouco melhor o impacto delas nos indicadores financeiros.

Em relação ao Flamengo, é possível verificar um crescimento constante do ativo entre 2013 e 2019 , tendo mais que duplicado no período, onde saltou de $\mathrm{R} \$ 382$ milhões para $\mathrm{R} \$ 878$ milhões. O ativo circulante acompanhou a trajetória, com exceção entre os anos de 2015 e 2016, quando foram celebrados diversos acordos de natureza trabalhista e cível, que impactaram negativamente no caixa, mas aliviaram o passivo não circulante. Além disso, a queda de $61 \%$ em Contas a Receber é o outro fator que impactou negativamente 0 ativo circulante entre 2015 e 2016. 
O desempenho esportivo de 2019, que trouxe os títulos de campeão brasileiro e da Libertadores ao clube, fez com que as rubricas contidas no ativo circulante disparassem em relação ao ano de 2018.

No que diz respeito ao ativo não circulante do Flamengo, houve crescimento de $113,15 \%$, puxado principalmente pelas vendas de jogadores, como Vinícius Júnior e Lucas Paquetá, em 2017 e 2018, respectivamente. As vendas desses jogadores geraram recursos na ordem de 80 milhões de euros, a serem recebidos de forma parcelada até 2020, o que explica também o crescimento acentuado da rubrica Contas a Receber do ativo circulante nos anos de 2018 e 2019.

Outro aspecto que impulsionou o aumento tanto de ativo circulante, como não circulante, foi o recebimento de bônus pela assinatura de contrato de venda dos direitos de transmissão dos jogos, cuja primeira parcela foi paga em 2016 no ato da assinatura, a segunda em 2019, e a última, em 2021.

Além disso, vale destacar que o intangível foi a rubrica cujo crescimento foi mais significativo, em torno de dez vezes, uma vez que em termos absolutos sua representatividade tem grande peso no total dos ativos. Os direitos econômicos dos atletas estão contidos e são a maior parte dessa rubrica.

No que tange o passivo do Flamengo, até 2019 o clube o diminuiu ano após ano, uma vez que realizou e passou a pagar o parcelamento de dívidas fiscais em 2013, o que pode ser visualizado com a diminuição de cerca de $37 \%$ das obrigações tributárias a partir daquele ano e aumentos nas rubricas de Contas a Pagar em relação a 2013.

Então, em 2019, mudou sua política de contratação de jogadores e passou a ser mais agressivo no mercado, inclusive no que diz respeito aos salários pagos, se endividando para tal, conforme apontam os crescimentos das rubricas de contas a pagar em comparação ao ano de 2018 , 67\% no passivo circulante e $2070 \%$ no passivo não circulante. É importante mencionar que em 2018 só houve aumento expressivo do passivo não circulante pelo fato de uma das parcelas da venda do Lucas Paquetá ter sido classificada como adiantamento.

No entanto, ao observar o patrimônio líquido do clube e sua evolução, é possível verificar que apesar de ter aumentado significativamente seu passivo em $2019(27,4 \%)$, o mesmo tem seguido uma trajetória para reverter seus prejuízos acumulados, passando a ter patrimônio líquido positivo a partir de 2017. 
Quanto aos balanços do Borussia Dortmund, é necessário destrinchar o crescimento de $431 \%$ do imobilizado entre as temporadas 2012/2013 e $2013 / 2014$, assim como a queda de $90 \%$ dos investimentos. Isso ocorreu pois alguns dos ativos de empresas subsidiárias do clube alemão foram incorporados ao balanço do mesmo. Tais rubricas seguem constantes até o final do período analisado.

O aumento de $115 \%$ do intangível pode ser justificado por meio da compra de direitos de jogadores, principalmente. A queda de $81 \%$ em Contas a Receber, dentro do ativo circulante, está relacionada a uma campanha pior que na temporada anterior na principal competição disputada na Europa, a Liga dos Campeões, quando chegou à final. A queda ocorreu tanto em termos de premiação, como bilheteria e por conta de menor venda de jogadores.

Na temporada 2014/2015, o aumento de $29 \%$ do total do ativo está relacionado com a maior venda de jogadores, que fez com que o caixa disponível saltasse $215 \%$ e devido ao crescimento do intangível, na ordem de $56 \%$, representado pela compra de atletas.

Nos anos posteriores, o crescimento do total do ativo desacelera, mas se mantém constante, havendo crescido $77 \%$ entre o início e o fim do período analisado. A principal razão que explica tal evolução é a venda de jogadores de e bons resultados operacionais, com destaque para o crescimento de $352 \%$ da rubrica Contas a Receber entre as temporadas 2014/2015 e 2015/2016.

No que diz respeito ao passivo do Borussia Dortmund, a principal rubrica a ser analisada é a de patrimônio líquido, cujo crescimento desde o início do período analisado até $2018 / 2019$ foi de $113 \%$, algo proporcionado pelos sucessivos resultados positivos em cada período, pelos fatores mencionados anteriormente. É importante observar que o salto de $73 \%$ no patrimônio líquido entre $2013 / 2014$ e $2014 / 2015$ se deu pelo aumento de $81 \%$ do capital social, por meio de duas novas emissões de ações ocorridas no período. No mais, o crescimento das rubricas se deu de forma orgânica e constante. 


\subsection{Análise Vertical dos Balanços Patrimoniais}

Tabela 5: Análise Vertical dos Ativos do Flamengo ( $R$ \$ 1.000)

\begin{tabular}{|l|c|c|c|c|c|c|c|c|c|c|c|c|c|}
\hline \multicolumn{10}{|c|}{ Balanço Patrimonial } \\
\hline \multicolumn{1}{|c|}{ Ativo } & $\mathbf{2 0 1 9}$ & $\%$ An Ver & $\mathbf{2 0 1 8}$ & \% An Ver & $\mathbf{2 0 1 7}$ & $\%$ An Ver & $\mathbf{2 0 1 6}$ & $\%$ An Ver & $\mathbf{2 0 1 5}$ & $\%$ An Ver & $\mathbf{2 0 1 4}$ & $\%$ An Ver & $\mathbf{2 0 1 3}$ \\
\hline \multicolumn{1}{|c|}{ Ativo Circulante } & 202.467 & $23 \%$ & 86.668 & $15 \%$ & 62.312 & $10 \%$ & 45.615 & $9 \%$ & 113.686 & $25 \%$ & 104.207 & $24 \%$ & 64.740 \\
\hline Caixa Disponível & 87.649 & $43 \%$ & 8.016 & $9 \%$ & 11.935 & $19 \%$ & 12.526 & $27 \%$ & 27.257 & $24 \%$ & 18.030 & $17 \%$ & 12.034 \\
\hline Contas a Receber & 86.120 & $43 \%$ & 43.988 & $51 \%$ & 22.455 & $36 \%$ & 16.415 & $36 \%$ & 42.379 & $37 \%$ & 36.149 & $35 \%$ & 22.664 \\
\hline Adiantamentos & 16.383 & $8 \%$ & 1.325 & $2 \%$ & 2.602 & $4 \%$ & 1.584 & $3 \%$ & 1.212 & $1 \%$ & 1.241 & $1 \%$ & 390 \\
\hline Depósitos Judiciais & & - & 17.261 & $20 \%$ & 14.898 & $24 \%$ & 13.148 & $29 \%$ & 42.757 & $38 \%$ & 48.538 & $47 \%$ & 29.365 \\
\hline Outros & 12.315 & $6 \%$ & 16.077 & $19 \%$ & 10.422 & $17 \%$ & 1.942 & $4 \%$ & 81 & $0 \%$ & 249 & $0 \%$ & 286 \\
\hline \multicolumn{1}{|c|}{ Ativo Não Circulante } & 676.359 & $77 \%$ & 503.582 & $85 \%$ & 536.041 & $90 \%$ & 437.804 & $91 \%$ & 337.686 & $75 \%$ & 325.703 & $76 \%$ & 317.310 \\
\hline Contas a Receber & 3.287 & $0 \%$ & 10.611 & $2 \%$ & 114.573 & $21 \%$ & 59.718 & $14 \%$ & 4.456 & $1 \%$ & 3.519 & $1 \%$ & 3.275 \\
\hline Depósitos Judiciais & 39.539 & $6 \%$ & 22.202 & $4 \%$ & 22.846 & $4 \%$ & 12.673 & $3 \%$ & 2.537 & $1 \%$ & 3.393 & $1 \%$ & \\
\hline Investimentos & 104.948 & $16 \%$ & 104.966 & $21 \%$ & 130.485 & $24 \%$ & 132.519 & $30 \%$ & 136.584 & $40 \%$ & 138.625 & $43 \%$ & 147.042 \\
\hline Imobilizado & 202.432 & $30 \%$ & 187.800 & $37 \%$ & 174.608 & $33 \%$ & 158.753 & $36 \%$ & 147.146 & $44 \%$ & 142.591 & $44 \%$ & 134.542 \\
\hline Intangível & 326.153 & $48 \%$ & 178.003 & $35 \%$ & 93.529 & $17 \%$ & 74.141 & $17 \%$ & 46.963 & $14 \%$ & 37.575 & $12 \%$ & 32.450 \\
\hline & & & & & & & & & & & & & \\
\hline \multicolumn{1}{|c|}{} & & & & & & & & & & & & \\
\hline Total do Ativo & 878.826 & $100 \%$ & 590.250 & $100 \%$ & 598.353 & $100 \%$ & 483.419 & $100 \%$ & 451.372 & $100 \%$ & 429.910 & $100 \%$ & 382.050 \\
\hline
\end{tabular}

Fonte: Elaboração própria

Tabela 6: Análise Vertical do Passivos + Patrimônio Líquido do Flamengo (R\$1.000)

\begin{tabular}{|c|c|c|c|c|c|c|c|c|c|c|c|c|c|}
\hline \multicolumn{10}{|c|}{ Balanço Patrimonial } \\
\hline \multicolumn{1}{|c|}{ Passivo } & $\mathbf{2 0 1 9}$ & $\%$ An Ver & $\mathbf{2 0 1 8}$ & $\%$ An Ver & $\mathbf{2 0 1 7}$ & $\%$ An Ver & $\mathbf{2 0 1 6}$ & $\%$ An Ver & $\mathbf{2 0 1 5}$ & $\%$ An Ver & $\mathbf{2 0 1 4}$ & $\%$ An Ver & $\mathbf{2 0 1 3}$ \\
\hline Passivo Circulante & 317.127 & $36 \%$ & 201.859 & $34 \%$ & 206.331 & $34 \%$ & 222.583 & $46 \%$ & 263.716 & $58 \%$ & 274.697 & $64 \%$ & 221.958 \\
\hline Contas a Pagar & 162.226 & $51 \%$ & 97.111 & $48 \%$ & 74.291 & $36 \%$ & 131.677 & $59 \%$ & 150.796 & $57 \%$ & 127.950 & $47 \%$ & 89.560 \\
\hline Obrigações Trabalhistas & 96.000 & $30 \%$ & 38.814 & $19 \%$ & 35.731 & $17 \%$ & 28.640 & $13 \%$ & 22.738 & $9 \%$ & 32.197 & $12 \%$ & 37.554 \\
\hline Provisão para Contigência & & - & 12.438 & $6 \%$ & 27.365 & $13 \%$ & 26.165 & $12 \%$ & 55.099 & $21 \%$ & 74.653 & $27 \%$ & 64.545 \\
\hline Receitas a Realizar & 58.901 & $19 \%$ & 53.496 & $27 \%$ & 68.944 & $33 \%$ & 36.101 & $16 \%$ & 35.083 & $13 \%$ & 39.896 & $15 \%$ & 30.119 \\
\hline Passivo Não Circulante & 433.568 & $49 \%$ & 387.163 & $66 \%$ & 328.080 & $55 \%$ & 355.993 & $74 \%$ & 436.295 & $97 \%$ & 534.302 & $124 \%$ & 603.493 \\
\hline Contas a Pagar & 64.906 & $15 \%$ & 2.991 & $1 \%$ & 16.491 & $5 \%$ & 32.289 & $9 \%$ & 81.536 & $19 \%$ & 84.914 & $16 \%$ & 97.781 \\
\hline Obrigações Tributárias & 217.593 & $50 \%$ & 281.273 & $73 \%$ & 278.560 & $85 \%$ & 264.241 & $74 \%$ & 250.238 & $57 \%$ & 329.222 & $62 \%$ & 349.131 \\
\hline Provisão para Contigência & 86.451 & $20 \%$ & 30.223 & $8 \%$ & 16.562 & $5 \%$ & 25.713 & $7 \%$ & 41.618 & $10 \%$ & 39.331 & $7 \%$ & 54.898 \\
\hline Receitas a Realizar & 64.618 & $15 \%$ & 72.675 & $19 \%$ & 16.547 & $5 \%$ & 33.750 & $9 \%$ & 62.903 & $14 \%$ & 80.835 & $15 \%$ & 101.683 \\
\hline Patrimônio Líquido & 128.131 & $15 \%$ & 1.228 & $0 \%$ & 63.942 & $11 \%$ & -95.157 & $-20 \%$ & -248.639 & $-55 \%$ & -379.089 & $-88 \%$ & -443.401 \\
\hline Patrimônio Social & 240.011 & $187 \%$ & 243.341 & $19816 \%$ & 245.907 & $385 \%$ & 248.896 & $-262 \%$ & 259.123 & $-104 \%$ & 262.114 & $-69 \%$ & 261.447 \\
\hline Resultado Acumulado & -111.880 & $-87 \%$ & -242.113 & $-19716 \%$ & -181.965 & $-285 \%$ & -344.053 & $362 \%$ & -507.762 & $204 \%$ & -641.203 & $169 \%$ & -704.848 \\
\hline & & & & & & & & & & & & & \\
\hline Total do Passivo & 878.826 & $100 \%$ & 590.250 & $100 \%$ & 598.353 & $100 \%$ & 483.419 & $100 \%$ & 451.372 & $100 \%$ & 429.910 & $100 \%$ & 382.050 \\
\hline
\end{tabular}

Fonte: Elaboração própria 
Tabela 7: Análise Vertical dos Ativos do Borussia Dortmund (€ 1.000)

\begin{tabular}{|l|c|c|c|c|c|c|c|c|c|c|c|c|c|}
\hline \multicolumn{10}{|c|}{ Balanço Patrimonial } \\
\hline \multicolumn{1}{|c|}{ Ativo } & $\mathbf{2 0 1 8 / 1 9}$ & $\%$ An Ver & $\mathbf{2 0 1 7 / 1 8}$ & $\%$ An Ver & $\mathbf{2 0 1 6 / 1 7}$ & $\%$ An Ver & $\mathbf{2 0 1 5 / 1 6}$ & $\%$ An Ver & $\mathbf{2 0 1 4 / 1 5}$ & $\%$ An Ver & $\mathbf{2 0 1 3 / 1 4}$ & $\%$ An Ver & $\mathbf{2 0 1 2 / 1 3}$ \\
\hline \multicolumn{1}{|c|}{ Ativo Circulante } & 121.952 & $24 \%$ & 147.027 & $30 \%$ & 143.294 & $29 \%$ & 162.698 & $38 \%$ & 90.526 & $23 \%$ & 36.979 & $12 \%$ & 84.993 \\
\hline Caixa Disponível & 52.120 & $43 \%$ & 54.911 & $37 \%$ & 45.360 & $32 \%$ & 49.682 & $31 \%$ & 53.019 & $59 \%$ & 16.858 & $46 \%$ & 11.539 \\
\hline Contas a Receber & 39.085 & $32 \%$ & 62.819 & $43 \%$ & 62.228 & $43 \%$ & 90.678 & $56 \%$ & 20.057 & $22 \%$ & 12.413 & $34 \%$ & 66.756 \\
\hline Adiantamentos & - & - & - & - & - & - & - & - & - & - & - & - & - \\
\hline Depósitos Judiciais & - & - & - & - & - & - & - & - & - & - & - & - & - \\
\hline Outros & 30.747 & $25 \%$ & 29.297 & $20 \%$ & 35.706 & $25 \%$ & 22.338 & $14 \%$ & 17.450 & $19 \%$ & 7.708 & $21 \%$ & 6.698 \\
\hline \multicolumn{1}{|c|}{ Ativo Não Circulante } & 391.754 & $76 \%$ & 349.426 & $70 \%$ & 344.415 & $71 \%$ & 269.708 & $62 \%$ & 300.168 & $77 \%$ & 265.861 & $88 \%$ & 204.967 \\
\hline Contas a Receber & - & - & - & - & - & - & - & - & - & - & - & - & - \\
\hline Depósitos Judiciais & - & - & - & - & - & - & - & - & - & - & - & - & - \\
\hline Investimentos & 11.743 & $3 \%$ & 13.770 & $4 \%$ & 15.650 & $5 \%$ & 15.366 & $6 \%$ & 14.930 & $5 \%$ & 14.345 & $5 \%$ & 140.367 \\
\hline Imobilizado & 195.553 & $50 \%$ & 195.487 & $56 \%$ & 187.579 & $54 \%$ & 189.154 & $70 \%$ & 188.662 & $63 \%$ & 189.565 & $71 \%$ & 35.729 \\
\hline Intangível & 184.458 & $47 \%$ & 140.169 & $40 \%$ & 141.186 & $41 \%$ & 65.188 & $24 \%$ & 96.576 & $32 \%$ & 61.951 & $23 \%$ & 28.871 \\
\hline & & & & & & & & & & & & & \\
\hline
\end{tabular}

Fonte: Elaboração própria

Tabela 8: Análise Vertical dos Passivos + Patrimônio Líquido do Borussia Dortmund $(€ 1.000)$

\begin{tabular}{|c|c|c|c|c|c|c|c|c|c|c|c|c|c|}
\hline \multicolumn{14}{|c|}{ Balanço Patrimonial } \\
\hline Passivo & $2018 / 19$ & $\%$ An Ver & $2017 / 18$ & $\%$ An Ver & $2016 / 17$ & $\%$ An Ver & $2015 / 16$ & $\%$ An Ver & $2014 / 15$ & $\%$ An Ver & $2013 / 14$ & $\%$ An Ver & $2012 / 13$ \\
\hline Passivo Circulante & 102.511 & $20 \%$ & 97.277 & $20 \%$ & 119.465 & $24 \%$ & 67.358 & $16 \%$ & 61.972 & $16 \%$ & 78.511 & $26 \%$ & 79.317 \\
\hline Contas a Pagar & 77.353 & $75 \%$ & 68.914 & $71 \%$ & 89.906 & $75 \%$ & 35.076 & $52 \%$ & 25.699 & $41 \%$ & 37.691 & $48 \%$ & 41.204 \\
\hline Obrigações Trabalhistas & 36 & $0 \%$ & 29 & $0 \%$ & 19 & $0 \%$ & 15 & $0 \%$ & 14 & $0 \%$ & 16 & $0 \%$ & 8 \\
\hline Provisão para Contigência & - & - & - & - & - & - & - & - & - & - & - & - & - \\
\hline Receitas a Realizar & 25.122 & $25 \%$ & 28.334 & $29 \%$ & 29.540 & $25 \%$ & 32.267 & $48 \%$ & 36.259 & $59 \%$ & 40.804 & $52 \%$ & 38.105 \\
\hline Passivo Não Circulante & 21.677 & $4 \%$ & 29.983 & $6 \%$ & 19.937 & $4 \%$ & 17.561 & $4 \%$ & 4.899 & $1 \%$ & 37.499 & $12 \%$ & 28.237 \\
\hline Contas a Pagar & 8.705 & $40 \%$ & 12.274 & $41 \%$ & 7.096 & $36 \%$ & 3.420 & $19 \%$ & 0 & $0 \%$ & 32.189 & $86 \%$ & 14.858 \\
\hline Obrigações Tributárias & 807 & $4 \%$ & 1.946 & $6 \%$ & 590 & $3 \%$ & 5.072 & $29 \%$ & 710 & $14 \%$ & 398 & $1 \%$ & 3.956 \\
\hline Provisão para Contigência & 12.165 & $56 \%$ & 15.763 & $53 \%$ & 12.251 & $61 \%$ & 9.069 & $52 \%$ & 4.189 & $86 \%$ & 4.912 & $13 \%$ & 9.423 \\
\hline Receitas a Realizar & - & - & - & - & - & - & - & - & - & - & - & - & - \\
\hline Patrimônio Líquido & 389.518 & $76 \%$ & 369.193 & $74 \%$ & 348.307 & $71 \%$ & 347.487 & $80 \%$ & 323.823 & $83 \%$ & 186.830 & $62 \%$ & 182.406 \\
\hline Patrimônio Social & 363.674 & $93 \%$ & 342.788 & $93 \%$ & 341.968 & $98 \%$ & 319.225 & $92 \%$ & 319.223 & $99 \%$ & 176.272 & $94 \%$ & 129.148 \\
\hline Resultado no Período & 25.844 & $7 \%$ & 26.405 & $7 \%$ & 6.339 & $2 \%$ & 28.262 & $8 \%$ & 4.600 & $1 \%$ & 10.558 & $6 \%$ & 53.258 \\
\hline Total do Passivo & 513.706 & $100 \%$ & 496.453 & $100 \%$ & 487.709 & $100 \%$ & 432.406 & $100 \%$ & 390.694 & $100 \%$ & 302.840 & $100 \%$ & 289.960 \\
\hline
\end{tabular}

Fonte: Elaboração própria

Ao analisar as rubricas do Flamengo de forma vertical, é possível verificar que não houve mudanças significativas na razão entre ativo circulante e ativo total, se mantendo na faixa de $1 / 4$ durante o período analisado. A queda entre os anos de 2016 e 2017 se justifica pela de venda de jogadores de forma parcelada, com a maior parte dos valores das negociações sendo recebido em 2018 e 2019.

Dentro do ativo não circulante, o destaque na análise em relação ao Flamengo se deu em torno do crescimento do intangível, ou seja, um aumento de dez vezes desde o início do período analisado, que passou a representar $48 \%$ do ativo não circulante em 2019. A compra de diversos jogadores, principalmente entre os anos de 2017 e 2019, impulsionou o crescimento dessa rubrica. 
A partir dos acordos firmados em 2015 e 2016, houve uma queda na representatividade da rubrica de depósitos judiciais dentro ativo circulante, tendo sido zerada em 2019. No entanto, devido ao incêndio ocorrido no centro de treinamentos do Flamengo em 2019 - incidente que causou a morte de dez jogadores de base do rubro-negro - a rubrica de depósitos judiciais no ativo não circulante, inexistente no início do período da análise, passou representar $6 \%$ do ativo total. Tal rubrica indica a separação de valores a serem pagos para as famílias das vítimas como forma de indenização, cujo pagamento é considerado iminente pelo clube dentro do âmbito jurídico.

Ao observar a parte dos passivos do Flamengo, é possível verificar a queda na representatividade das obrigações de curto prazo em relação ao passivo total, ou seja, a composição da dívida do clube, mudou ao longo dos anos. Antes, o passivo circulante representava $64 \%$ do passivo total, rubrica essa que apontava a asfixia financeira que o clube vivia antes da mudança de sua gestão em 2013. Ao final do período de análise, ela já havia se estabilizado na faixa de $36 \%$.

As obrigações foram cada vez mais sendo representadas dentro do passivo não circulante, que deixou de constituir 124\% do passivo total em 2013 para $49 \%$ em 2019. A principal rubrica que chama a atenção no passivo não circulante é a provisão para contingências, rubrica que saltou para $20 \%$ do passivo não circulante, devido aos valores reservados para acordos com as vítimas das famílias do incêndio do Ninho do Urubu.

Por fim, o esforço financeiro por parte do Flamengo para se reestruturar é notório, quando analisada a evolução do patrimônio líquido do clube, que deixou de ser negativo e passou a representar $15 \%$ do passivo total a partir de sucessivos resultados financeiros positivos.

A análise dos balanços do Borussia Dortmund indica que durante 0 período de analisado, praticamente todas as rubricas se mantiveram estáveis. No caso do ativo circulante, as mudanças na razão entre o mesmo e ativo total foram mínimas, passando de $12 \%$ no primeiro ano para $24 \%$ no último. No que diz respeito ao ativo não circulante sobre o total, a mudança também foi de doze pontos percentuais entre 2012/2013 e 2018/2019. O principal ponto a destacar passa pelo crescimento do intangível, que passou a representar $47 \%$ do ativo não circulante, em sua maioria representada pelos direitos econômicos de jogadores.

No que tange o passivo do clube alemão, não há nenhuma rubrica que se destaque, uma vez que todas as proporções em relação ao passivo total 
apresentaram pouca variação entre os anos analisados, o que indica bom planejamento, controle e estabilidade da gestão.

\subsection{Comparativo entre Clubes}

\subsubsection{Liquidez Geral}

Tabela 9: Comparação Liquidez Geral

\begin{tabular}{|c|c|c|c|c|c|c|c|}
\hline \multicolumn{10}{|c|}{ Liquidez Geral } \\
\hline & Ano 7 & Ano 6 & Ano 5 & Ano 4 & Ano 3 & Ano 2 & Ano 1 \\
\hline Flamengo & 0,33 & 0,20 & 0,37 & 0,20 & 0,17 & 0,14 & 0,08 \\
\hline Borussia & 0,98 & 1,16 & 1,03 & 1,92 & 1,35 & 0,32 & 0,79 \\
\hline
\end{tabular}

Fonte: Elaboração própria

O indicador de liquidez geral ilustra a capacidade da instituição de honrar seus compromissos. Quanto maior o número, melhor a situação financeira do clube, uma vez que ele não precisaria gerar novas receitas para saldar suas obrigações.

Nesse caso, é possível concluir que o Flamengo está bastante atrás do Borussia Dortmund, visto que os números do clube alemão são superiores em todos os anos, partindo de 0,79 no $1^{\circ}$ ano até 0,98 no último. No entanto, a evolução do indicador rubro-negro tem sido de sucessivas altas ano após ano, apesar de ter caído no ano 6 , o que pode ser justificado pelas duas maiores vendas de jogadores da história do clube (Vinícius Júnior e Lucas Paquetá), no ano anterior, algo que inflou as receitas do clube de forma extraordinária. Enquanto isso, o índice do Borussia flutua entre os anos. Logo, é possível inferir que caso continue nessa tendência, o clube brasileiro pode se aproximar e até alcançar o clube europeu. 


\subsubsection{Liquidez Corrente}

Tabela 10: Comparação Liquidez Corrente

\begin{tabular}{|c|c|c|c|c|c|c|c|}
\hline \multicolumn{7}{|c|}{ Liquidez Corrente } \\
\hline & Ano 7 & Ano 6 & Ano 5 & Ano 4 & Ano 3 & Ano 2 & Ano 1 \\
\hline Flamengo & 0,64 & 0,43 & 0,30 & 0,20 & 0,43 & 0,38 & 0,29 \\
\hline Borussia & 1,19 & 1,51 & 1,20 & 2,42 & 1,46 & 0,47 & 1,07 \\
\hline
\end{tabular}

Fonte: Elaboração própria

O índice acima ilustra a capacidade dos clubes de pagar suas obrigações de curto prazo com as receitas de curto prazo. Quando maior for o número, melhor.

Assim como no indicador anterior, o Borussia Dortmund é superior em todos os anos, com índice maior que 1 em seis dos sete anos analisados, ilustrando uma situação bastante confortável. O Flamengo tem mostrado evolução quase constante - a única exceção é no 4º ano da análise -, apesar de o indicador nunca ter ultrapassado o 1 , tendo sido observado 0,29 no primeiro ano e 0,64 no último. Portanto, a diferença tende a diminuir, caso a gestão rubronegra se mantenha comprometida com a saúde financeira do clube.

\subsubsection{Liquidez Imediata}

Tabela 11: Comparação Liquidez Imediata

\begin{tabular}{|c|c|c|c|c|c|c|c|}
\hline \multicolumn{7}{|c|}{ Liquidez Imediata } \\
\hline & Ano 7 & Ano 6 & Ano 5 & Ano 4 & Ano 3 & Ano 2 & Ano 1 \\
\hline Flamengo & 0,28 & 0,04 & 0,06 & 0,06 & 0,10 & 0,07 & 0,05 \\
\hline Borussia & 0,51 & 0,56 & 0,38 & 0,74 & 0,86 & 0,21 & 0,15 \\
\hline
\end{tabular}

Fonte: Elaboração própria

O índice relaciona o caixa disponível com as obrigações de curto prazo. Sendo assim, mostra a capacidade de honrar tais compromissos apenas os ativos disponíveis.

Com isso, é possível entender a razão pela qual os indicadores de ambos os clubes ficam mais próximos ao 0 do que nos casos anteriores. Como o fechamento da temporada brasileira se dá em dezembro, quando incorrem custos trabalhistas, e o pagamento de parte dos direitos de televisão, assim como de algumas premiações, é efetuado apenas no ano seguinte, há um certo impacto negativo nos indicadores flamenguistas. 
A evolução do indicador rubro-negro, como nos outros, indica tendência de crescimento, apesar de estar ainda um pouco abaixo em relação ao do indicador do clube alemão no último ano da análise: 0,28 e 0,51, respectivamente.

\subsubsection{Participação do Capital de Terceiros}

Tabela 12: Comparação Participação do Capital de Terceiros

\begin{tabular}{|c|c|c|c|c|c|c|c|}
\hline \multicolumn{1}{|c|}{ Participação do Capital de Terceiros } \\
\hline & Ano 7 & Ano 6 & Ano 5 & Ano 4 & Ano 3 & Ano 2 & Ano 1 \\
\hline Flamengo & 5,86 & 479,66 & 8,36 & $-6,08$ & $-2,82$ & $-2,13$ & $-1,86$ \\
\hline Borussia & 0,32 & 0,34 & 0,40 & 0,24 & 0,21 & 0,62 & 0,59 \\
\hline
\end{tabular}

Fonte: Elaboração própria

O índice demonstra quão dependente do capital externo em relação ao seu próprio capital os clubes são.

No entanto, a análise é ineficiente, uma vez que nos primeiros quatro anos não é possível compreender tão bem a situação rubro-negra, visto que seu indicador é negativo, devido aos déficits acumulados ao longo do histórico do clube. É possível apenas concluir que o clube é bastante dependente do capital de terceiros, enquanto o Borussia Dortmund é pouco dependente, principalmente a partir do terceiro ano analisado, quando ele atinge 0,21 e até o ano 7 se mantém confortavelmente abaixo dos 0,59 verificados no primeiro ano.

É importante mencionar que, como nos indicadores anteriores, a trajetória do Flamengo tem sido de crescimento, visto que reverteu indicadores negativos a partir do ano 5 . No entanto, o último número analisado (no último ano) ainda é bastante alto, ilustrando a dependência do Flamengo desse tipo de capital: 5,86.

\subsubsection{Composição do Endividamento}

Tabela 13: Comparação Composição do Endividamento

\begin{tabular}{|c|c|c|c|c|c|c|c|}
\hline \multicolumn{1}{|c|}{ Composição do Endividamento } \\
\hline & Ano 7 & Ano 6 & Ano 5 & Ano 4 & Ano 3 & Ano 2 & Ano 1 \\
\hline Flamengo & 0,42 & 0,34 & 0,39 & 0,38 & 0,38 & 0,34 & 0,27 \\
\hline Borussia & 0,83 & 0,76 & 0,86 & 0,79 & 0,93 & 0,68 & 0,74 \\
\hline
\end{tabular}

Fonte: Elaboração própria 
A partir desse índice, é possível entender melhor qual é a natureza das obrigações do clube, se são de curto prazo ou não. Quanto menor for esse indicador, melhor, pois demostra que a natureza dessas obrigações é de longo prazo.

Olhar apenas para o número do indicador é algo que poderia tornar a análise incorreta, visto que o indicador rubro-negro é apenas menor que o do Borussia, pois a razão do cálculo é: passivo circulante sobre a soma de passivo circulante e passivo não circulante. Como o Flamengo possui uma rubrica de passivo não circulante bastante alta no início do período da análise, isso acaba distorcendo a mesma, pois 0,27 no primeiro ano não condiz com a realidade do clube. No entanto, ao olhar para o balanço completo, é possível visualizar isso.

Deste modo, após esta importante ressalva, assim como nos primeiros indicadores, pode-se apontar a superioridade do clube alemão. Apesar disso, é importante mencionar que o Flamengo tem buscado reduzir o seu passivo não circulante e tem obtido êxito, encurtando cada vez mais a diferença em relação ao clube alemão.

\subsubsection{Imobilização do Patrimônio Líquido}

Tabela 14: Comparação da Imobilização do Patrimônio Líquido

\begin{tabular}{|c|c|c|c|c|c|c|c|}
\hline \multicolumn{8}{|c|}{ Imobilização do Patrimônio Líquido } \\
\hline & Ano 7 & Ano 6 & Ano 5 & Ano 4 & Ano 3 & Ano 2 & Ano 1 \\
\hline Flamengo & 4,94 & 383,36 & 6,23 & $-3,84$ & $-1,33$ & $-0,84$ & $-0,71$ \\
\hline Borussia & 1,01 & 0,95 & 0,99 & 0,78 & 0,93 & 1,42 & 1,12 \\
\hline
\end{tabular}

Fonte: Elaboração própria

O indicador mostra qual a proporção dos ativos permanentes do clube em relação ao seu patrimônio líquido. Como no caso do Flamengo o patrimônio líquido é negativo nos primeiros quatro anos, o índice não ilustra tão bem o que deveria, dificultando uma melhor análise. Em geral, quanto maior ele for, mais saudável o clube pode ser considerado.

Entretanto, no ano 6, quando o indicador apresenta 383,36, não significa que o Flamengo esteja tão confortável assim, pois ao olhar o balanço completo, é possível concluir que tal fator ocorreu devido ao patrimônio líquido rubro-negro ser extremamente baixo e o clube ter investido bastante na compra de jogadores a partir do ano 5, elevando assim seu intangível. 
Quanto ao clube alemão, basta dizer que em todos os anos ele teve seu índice acima ou próximo de 1, ilustrando sua saúde financeira, cuja origem aconteceu também pelo fato de a liga alemã ter várias regras que ajudam a impedir sucessivas gestões catastróficas, como no caso rubro-negro. A solidez do clube alemão se deu também pelas exigências de seus investidores e regulação de órgãos responsáveis, visto que é uma instituição de capital aberto e listada em bolsa.

\subsubsection{Margem Líquida}

Tabela 15: Comparação Margem Líquida

\begin{tabular}{|c|c|c|c|c|c|c|c|}
\hline \multicolumn{10}{|c|}{ Margem Líquida } \\
\hline & Ano 7 & Ano 6 & Ano 5 & Ano 4 & Ano 3 & Ano 2 & Ano 1 \\
\hline Flamengo & 0,07 & 0,09 & 0,26 & 0,32 & 0,38 & 0,19 & $-0,08$ \\
\hline Borussia & 0,18 & 0,17 & 8,09 & 0,97 & 0,15 & 0,55 & 0,87 \\
\hline
\end{tabular}

Fonte: Elaboração própria

O indicador aponta a razão entre lucro líquido e receita líquida. Quanto maior for o número, melhor.

Conforme é possível verificar, trata-se de um indicador onde o Flamengo é competitivo em comparação com o clube alemão e mesmo assim, perde em seis dos sete anos, por mais que no $5^{\circ}$ ano do Borussia Dortmund tenha tido uma distorção, visto que sua receita líquida foi bem baixa e não seu lucro líquido alto.

Isso indica que ambos os clubes têm tido sucessivos superávits, excluindo o ano 1 do clube do Rio de Janeiro, onde o mesmo havia acabado de mudar sua gestão e apresentou indicador negativo de 0,08.

\subsubsection{ROA}

Tabela 16: Comparação ROA

\begin{tabular}{|c|c|c|c|c|c|c|c|}
\hline \multicolumn{1}{|c|}{ ROA } \\
\hline & Ano 7 & Ano 6 & Ano 5 & Ano 4 & Ano 3 & Ano 2 & Ano 1 \\
\hline Flamengo & 0,07 & 0,08 & 0,27 & 0,32 & 0,29 & 0,15 & $-0,05$ \\
\hline Borussia & 0,05 & 0,05 & 0,01 & 0,07 & 0,01 & 0,03 & 0,18 \\
\hline
\end{tabular}

Fonte: Elaboração própria 
O indicador ROA representa o lucro líquido sobre os ativos dos clubes. Quanto maior for, melhor.

No primeiro ano do Flamengo, conforme dito anteriormente, houve prejuízo, logo o indicador se apresenta negativo. Entre os anos 2 e 5, o Flamengo se mostra superior, chegando a apresentar índice 0,27 no ano 5, muito superior ao do Borussia Dortmund, de 0,01 no mesmo ano.

Isso ocorre, pois o lucro flamenguista é bastante elevado em todos os anos a partir do segundo, enquanto o Borussia Dortmund tem apenas lucros pequenos ano a ano.

\subsubsection{ROE}

Tabela 17: Comparação ROE

\begin{tabular}{|c|c|c|c|c|c|c|c|}
\hline \multicolumn{1}{|c|}{ ROE } \\
\hline & Ano 7 & Ano 6 & Ano 5 & Ano 4 & Ano 3 & Ano 2 & Ano 1 \\
\hline Flamengo & 0,49 & 37,37 & 2,49 & $-1,61$ & $-0,52$ & $-0,17$ & - \\
\hline Borussia & 0,07 & 0,07 & 0,02 & 0,08 & 0,01 & 0,06 & 0,29 \\
\hline
\end{tabular}

Fonte: Elaboração própria

Referido indicador mostra a razão entre lucro líquido e patrimônio líquido e quanto maior, melhor.

No entanto, apesar de o clube do Rio de Janeiro ter obtido vários resultados positivos em relação ao seu lucro, a análise fica distorcida e até se torna inviável no primeiro ano, onde tanto lucro, quanto patrimônio líquido foram negativos.

Até o ano 4, o patrimônio líquido segue negativo, impedindo uma análise que represente bem a situação desse indicador de rentabilidade, que como em todos dessa natureza, o Flamengo levaria vantagem, caso não tivesse um histórico tão ruim de gestões anteriores a 2013 - e pode ser verificado a partir do ano 5. A distorção do ano 6 também se dá pelo fato de o patrimônio líquido do Flamengo ser muito baixo, após a reversão da negatividade ocorrida até o ano 4 .

Sendo assim, é possível inferir que, caso persista uma gestão comprometida como a atual, o Flamengo deve passar a apresentar números bem superiores aos do Borussia no futuro. 


\section{Conclusão}

O principal objetivo desse estudo foi analisar, por meio do cálculo dos principais indicadores financeiros, a gestão financeira de dois dos clubes mais relevantes de seus respectivos países e com características parecidas. A partir do resultado obtido, pôde-se compará-los para situar a realidade de cada um e concluir qual dos dois vem realizando um trabalho melhor.

Para se chegar aos números apresentados, foi necessária a coleta de informações oriundas dos próprios clubes e auditadas por instituições independentes, por meio de seus próprios sites, com o intuito de aumentar o grau de confiabilidades delas. Além disso, a realização de cálculos para obtenção dos índices se fez necessária para que pudesse ser efetuada a comparação entre os clubes.

A ideia inicial do trabalho foi alterada por conta da inexistência de informação confiável e sem distorção em boa parte dos clubes europeus e principalmente dos clubes brasileiros que pudessem ser similares em termos de organização e tamanho. Tal fato teve influência direta na escolha por dois clubes que disponibilizassem informações confiáveis, como Flamengo e Borussia Dortmund.

A primeira conclusão trazida pelo trabalho se deu em torno da discrepância de organização dos clubes. Por mais que o Flamengo tenha mudado o rumo de sua gestão financeira e tenha entrado nos eixos de uma condução financeira saudável, a realidade ainda é distante, pois o histórico de administrações financeiras catastróficas é vasto e a mudança ocorreu apenas em 2013, não possibilitando a reversão tão rápida desses resultados para tornar a comparação competitiva. As exigências de órgãos reguladores e da própria liga alemã fizeram com que esse movimento de organização de governança fosse uma realidade muito antes do que ocorreu no Flamengo, possibilitando ao Borussia Dortmund atingir e consolidar tais resultados financeiros antes.

Entretanto, é possível observar que a evolução demonstrada ao longo dos anos analisados, em todos os indicadores financeiros do Flamengo, permite inferir que, caso continue nesse ritmo, a diferença deve diminuir, fazendo com que a realidade dos clubes se torne cada vez mais próxima. 
Também é necessário apontar que o resultado financeiro de clubes de futebol está bastante relacionado a fatores extraordinários, como a venda de atletas, assim como questões que fogem ao controle deles, como questões macroeconômicas - vide o impacto do câmbio nas negociações -, e tais fatores podem vir a causar distorções na análise.

Por fim, é essencial indicar que a gestão financeira eficiente torna os clubes mais competitivos, uma vez que eles passam a reinvestir seus recursos em jogadores melhores (intangível), além de ativos, como estádio e melhorias de instalações, por exemplo.

No entanto, a dependência dos clubes no que diz respeito ao desempenho de seus atletas não é algo que pode ser considerado previsível, uma vez que seus principais ativos não se tratam de máquinas e estão sujeitos a influências de diversos outros fatores que podem afetar negativamente sua performance.

Logo, é possível estabelecer um paralelo entre eficiência na gestão financeira e obtenção de resultados esportivos, mas não há garantia disso, devido aos inúmeros fatores que exercem influência nos resultados, e muitos deles não têm uma lógica definida. 


\section{Referências Bibliográficas}

ASSAF, N. Estrutura e análise de balanços: um enfoque econômicofinanceiro. 11. ed. São Paulo: Atlas, 2015.

BBC. O que a Copa vai deixar para o futebol brasileiro? Julho, 2014. Disponível em: <https://www.bbc.com/portuguese/noticias/2014/07/140710_wc2014_legado_cop a_rm_lab>. Acesso em: 03 nov. 2019.

Bundesliga. German Soccer Rules: 50+1 explained. Disponível em: $<$ https://www.bundesliga.com/en/news/Bundesliga/german-soccer-rules-50-1fifty-plus-one-explained-466583.jsp>. Acesso em: 29 mai. 2021.

CBF. As seleções campeãs mundiais desde 1930. Julho, 2018. Disponível em: $<$ https://www.cbf.com.br/futebol-brasileiro/noticias/index/as-selecoes-campeasmundiais-desde-1930>. Acesso em: 03 nov. 2019.

Cegalini, Vinicius Lordello. Dimensões e atributos que compõem a reputação de entidades esportivas brasileiras. Dissertação (mestrado) - Universidade Nove de Julho - UNINOVE, São Paulo, 2017. Disponível em: $<$ https://bibliotecatede.uninove.br/bitstream/tede/1679/2/Vinicius\%20Lordello\%2 0Cegalini.pdf>. Acesso em: 09 ago. 2021.

El País. Flamengo, de mais endividado a mais rico do Brasil. Março, 2018. Disponível em: <https://brasil.elpais.com/brasil/2018/03/02/deportes/1520024774_927536.html>. Acesso em: 07 nov. 2019.

Exame. Perspectivas do projeto de lei em tramitação para clube-empresa no Brasil. Maio, 2021. Disponível em: <https://exame.com/blog/esporte- 
executivo/perspectivas-do-projeto-de-lei-em-tramitacao-para-clube-empresa-nobrasil/>. Acesso em: 29 mai. 2021.

FIFA. History of Football - The Origins. Disponível em: $<$ https://www.fifa.com/about-fifa/who-we-are/the-game/>. Acesso em: 03 nov. 2019.

Flamengo. Flamengo consegue todas as certidões negativas de débito. Disponível em: <https://www.flamengo.com.br/noticias/flamengo/flamengoconsegue-todas-as-certidoes-negativas-de-debito>. Acesso em: 12 nov. 2019.

FONTES FILHO, Joaquim \& PICOLIN, Lidice M. Avaliando limitações e possibilidade da governança corporativa em empresas estatais. $\mathbf{X}$ Congreso Internacional del CLAD sobre la Reforma del Estado y de Adminitración Pública, Santiago. Disponível em: <http://www.clad.org.ve/fulltext/0052461.pdf>. Acesso em 14 nov. 2019.

Globo Esporte. Ronaldinho entra na Justiça e não é mais jogador do Flamengo. 2012 Maio, Disponível em: <http://globoesporte.globo.com/futebol/times/flamengo/noticia/2012/05/ronaldinh o-gaucho-entra-na-justica-e-nao-e-mais-jogador-do-flamengo.html>. Acesso em 07 nov. 2019.

Globo Esporte. Zinho lembra falta de falta de estrutura no Flamengo e elogia o Santos. Disponível em <http://globoesporte.globo.com/sp/santos-eregiao/futebol/times/santos/noticia/2013/09/zinho-lembra-falta-de-estrutura-noflamengo-e-elogia-o-santos.html>. Acesso em: 03 nov. 2019.

IFFHS. IFFHS History: The World's Best Player of the Century (1900-1999). 2017. Disponível em: <https://iffhs.de/iffhs-history-te-worlds-best-player-of-thecentury-1900-2000/>. Acesso em: 03 nov. 2019.

Lance. Não pagaram! Veja os clubes que já tiveram bens penhorados pela Justiça. Março, 2019. Disponível em: <https://www.lance.com.br/galeria- 
premium/nao-pagaram-veja-clubes-que-tiveram-bens-penhorados-pelajustica.html>. Acesso em 03 nov. 2019.

MARQUES, Maria da Conceição. Aplicação dos Princípios da Governança Corporativa ao Setor Público. RAC, v. 11, n. 2, Abr./Jun. 2007. Disponível em: <http://www.scielo.br/pdf/rac/v11n2/a02v11n2.pdf>. Acesso em: 19 nov. 2019.

Nielsen Sports. World Football Report. Stamford, 2018 Disponível em: $<$ https://nielsensports.com/wp-content/uploads/2014/12/Nielsen_WorldFootball2018-6.11.18.pdf>. Acesso em: 20 set. 2019. 